\title{
Trends and Patterns in Indian Board Structure
}

\author{
TARUn K SONI \& AKSHITA Arora
}

\begin{abstract}
The board structure of Indian companies has witnessed a sea change in terms of its size and composition. Our study presents the trends and patterns in board characteristics for the last two decades for the top 500 companies listed on the Bombay Stock Exchange. We have made an attempt to measure variations across different sectors, age groups, and time periods in the mean values of variables by using one-way ANOVA. The differences between mean values and variances of board characteristics have been examined for two different time periods (2002-2010 and 2011-2019) using paired t-test. The contribution of our study is the comprehensive analysis of board trends suggesting significant differences in board size and composition across different sectors and time periods. The significant differences across different sectors also highlight heterogeneity among different sectors which should be taken into account while formulating different policies related to corporate governance. The regulatory reforms can be treated as crucial milestones towards developing stronger corporate governance mechanisms in India and regulators may deliberate on taking the reforms to the next level. Further, future scholars may ponder over the company's strategic choices being followed for the functioning of their internal governance mechanism.
\end{abstract}

Keywords: Corporate governance; board size; board independence; outside directors; India

\section{INTRODUCTION}

The issue of corporate governance got its momentum when the Confederation of Indian Industry (CII) framed voluntary guidelines in the year 1998 for listed companies. Then, in the year 2000 , it became mandatory for the listed companies of a certain size to comply with new governance regulations, introduced through Clause 49 of the Listing Agreement. The Securities Exchange Board of India (SEBI) also formulated several committees to incorporate a better governance system in the corporate ecosphere. The major initiatives in the field of corporate governance in India include the CII code, committees such as Kumar Mangalam Birla Committee, Clause 49 of the Listing Agreement, The Companies (Amendment) Act, 2013, SEBI (Listing Obligations and Disclosure Requirements Regulations), etc. The purpose of the formation of several committees and periodic amendments is to review governance issues and bring transparency and accordingly, frame governance laws and reforms. The major reforms included increasing independent monitoring, splitting the roles of chairman and managing director and inclusion of women directors and women independent directors, the composition of several committees like audit, remuneration, and nomination committee, revamping the norms for appointment, removal, and remuneration of independent directors, etc. Consistent and concerted efforts are being made to enhance corporate credibility and governance standards and increase the shareholders' say in governance matters (Guha et al. 2019; Shikha, 2017; Gupta \& Shallu, 2014).
The academic research on the role of boards in decision-making has gained momentum amid recent corporate failures and scandals. After the Satyam scandal, the board of directors faced a lot of criticism from investors and stakeholders for being unable to protect shareholders' interests. The companies' board is held responsible for any erroneous decision and is expected to be proactive with the prime objective of satisfying all the stakeholders and improving the performance of the firm (Hashim et al. 2021). The Indian board structure has observed a sea change in the last two decades and our study presents trends and patterns in board size and independence for the top listed 500 companies on the Bombay Stock Exchange (BSE). The mandatory clause for the inclusion of independent directors in the board had made a notable impact on board size. The increase in the number of outside directors has led to the increase in total board size for many companies also (Arora \& Sharma 2016) as the addition of independent members was not accompanied by the removal of directors in any other category.

Our study tries to comprehend changing patterns in the board characteristics such as board size and board independence. It fills a significant gap by showcasing the changing patterns in the board structure across different sectors for the time span of eighteen years, i.e., 2002 to 2019. We examine how different policy changes over the years had an impact on the board composition of our sample companies. Further, an analysis of board structure has been done in relation to the company's age, sector, and time period. Thus, the study conducts a comprehensive 
analysis of corporate board trends from 2002 to 2019 across different sectors and years. The choice of sample period is guided by the data availability; moreover, the issue of optimal board structure gained prominence after the year 2000 when the governance norms got mandatory status after corporate governance committees highlighted the importance of higher governance disclosures. The companies had started making disclosures regarding board structure only after the recommendations of the committee.

Further, the sample period has been split into two time periods, i.e., 2002-2010 and 2011-2019. Post-Satyam scandal in the year 2009, the Ministry of Corporate Affairs issued several guidelines leading to significant changes in the governance reporting by public-listed firms, so we have also tried to capture the trends after the new guidelines. Further, we have chosen a representative sample of the top 500 companies from 22 important industries. The trends and patterns in board size and proportion of outside directors have been analyzed using the t-test and ANOVA method. The findings of the study suggest significant differences in the board measures across different sectors and sample periods, leading to larger boards and more independent members. The documented change in the board structure across different sectors and time period contribute to the new knowledge as an increase in board size can be linked to improved governance mechanism in the Indian context. Further, the significant differences across different sectors also highlight heterogeneity among different sectors which should be taken into account while formulating different policies related to corporate governance. The regulatory reforms can be treated as important milestones towards developing stronger governance mechanisms in emerging economies like India.

This paper is structured as follows: this section talks about the background of corporate governance in India, the sea change in board structure in the last few decades, etc. The next section provides literature on the board trends analyzed by previous studies. Thereafter, a discussion on data sources and a methodology has been provided. The results of the t-test and ANOVA have been presented and discussed in the next section. The concluding dialogue and future research directions are shared in the conclusion section.

\section{Literature Review, Theory AND Hypotheses Development}

An effective corporate board seeks to discharge diverse and challenging responsibilities. First, it provides a link between its stakeholders and the company (Herman 1981; Goodstein et al. 1994; Matter \& Ball 1985; Williamson 1996). Second, the board has a governance role, i.e., it should check and prevent management decisions that may lead to the decline in firm value. The third responsibility of boards is strategic decision-making on various functions and processes (Fama \& Jensen 1983).
It authorizes all important decisions such as investments, remuneration policy, dividend payouts, and primarily, all governance decisions. The boards have been the focus of substantial academic research and a considerable issue for policy-makers handling governance issues. Past studies have discussed the central role played by the board in maintaining effective governance in a company; for example, studies like Blair (1995) and Monks and Minow (2001) considered the boardroom as an important governance mechanism. The board has always been an important link to mitigate agency problems between owners and managers (Cadbury Report 1992). The corporate governance theories also promote diversity, vigilance, involvement, and independence in the boardroom. The pivotal role played by the board of directors makes it imperative to study its trends and patterns in the past, which may influence its effectiveness and decision-making. The discussion on selected board characteristics i.e. board size and proportion of outside directors is given below:

\section{BOARD SIZE (BS)}

The optimal board size of a company has been a matter of debate in many research studies. Scholars like Arora (2020) and Vaidya (2019) have tried to find out optimal board size in their academic research. SEBI (Listing Obligations and Disclosure Requirements) has issued recommendations for the minimum number of directors on boards, there is still silence on ideal board size. The agency theory advocates suggested large boards on the grounds of effective monitoring and bringing expertise by diversity and problem-solving capabilities (Arora \& Sharma 2016; Bhatt \& Bhattacharya 2015; Onyina \& Gyanor 2019; Le \& Thi 2016), thus improving firm performance (Dalton et al. 1999; Coles et al. 2008). On the other hand, smaller boards are preferred by companies for avoiding free-riding benefits and quick decision-making (Kumar \& Singh 2013) thus, better impact on firm value (Eisenberg et al. 1998). Also, smaller boards keep control of the excessive remuneration of directors (Soni \& Singh 2020). Also, studies like Martin and Herroro (2018) reported no significant relationship between board size and firm performance. A recent study by Ponomareva et al. (2021) has built a neo-institutional theory to examine how the conformity or non-conformity of the companies to governance practices has been linked with board compensation.

\section{PROPORTION OF OUTSIDE DIRECTORS (PO)}

The second variable of interest is outside directors. The agency theory advocates that independent directors are hired for the purpose of monitoring and supervision (Roy 2016). Studies have been conducted to know the significance of outside directors on board and test its impact on firm value in the Indian and international context. It has been observed that executive members 
also show more vigilance in the presence of outside directors (Finkelstein \& D'Aveni 1994; John \& Senbet 1998) and market reward such firms (Baysinger \& Butler 1985; Rosenstein \& Wyatt 1990). Through rigorous monitoring and supervision, outside directors may help the company to prevent financial fraud (Sharma 2004). The ability of effective monitoring would be clouded if the directors are not given independence, thus it is vital to have outside directors on the board (Ley et al. 2019) as their inclusion would enhance companies' compliance with rules and regulations (Azmi et al. 2020). At the same time, literature such as Mishra (2020); Nguyen et al. (2017) and alike have concluded a negative relationship between the proportion of independent directors and firm performance, probably because of information asymmetry between insiders and outside members. It would be interesting to note the patterns for BS and PO by observing its trends in case of mixed results.

\section{TRENDS AND PATTERNS}

The trends in board structure have been analyzed for developed economies such as the UK, US, etc. For example, the trends for UK firms have been examined by Guest (2008) for the time period 1981-2002. He revealed that the proportion of outside directors increased steadily over the entire sample period, which is also similar to the findings of Patro et al. (2009) for US firms. From 1981-88, the number of outside directors increased while insiders remained constant, hence board size increased in the UK (Guest 2008). He found that the average board size increased in the 1980s and then declined in the 1990s and more after the year 2000. According to Guest (2008), an increase in outside directors was offset by a larger decline in the number of insiders, hence board size declined from the year 1988 onwards. A similarity of trends was found by Linck et al. (2008) for US firms. When such analysis would be conducted for Indian firms, we would be able to comprehend the reasons for the continuous increase in the board size of companies. These trends may help us to understand the reason for the decline or rise in board size or independent directors.

For Indian companies, Arora and Sharma (2015) have analyzed the patterns in board characteristics, i.e. the board size, meeting, and outside directors. They have tried to understand the reasons behind the changing patterns in board parameters but have not evaluated board characteristics across different sectors or age groups of firms. Also, a comparative analysis by Mehrotra (2015) proved that board structure determinants differ across different institutional settings by showing that there is no significant change in the patterns of the leadership of US and Indian companies and US boards are more diverse in terms of having independent directors and women directors as compared to India. These previous studies, to the best of our knowledge, have not checked whether board characteristics are different across sectors or age groups of firms. Also, our study is a diverse analysis of board attributes in terms of time-span.
Our study tries to fill the vacuum by making an attempt to understand the trends in board characteristics in the Indian context. We try to see how board structure has changed with the changes in the regulatory framework. We examine if the board structure varies across different sectors for the chosen sample. Although, a study on Malaysian firms has been conducted by Amin and Nor (2019) from an industry specificities angle which focused on three major industries i.e. construction, manufacturing, and trading/services. We have moved a step ahead and taken a detailed sector-based classification for our study. We form a hypothesis that there is no significant difference in the mean values of board characteristics across different sectors. Further, we test if the variables of interest have changed among two different regimes i.e. 2002-2010 and 2011-2019. We hypothesize that there is no significant difference in the mean values of board characteristics across different time periods. The methodology for the same has been discussed in the next section.

\section{Methodology}

This section reports the sources of data and companies' selection for investigation. It is followed by descriptive statistics and a discussion on the statistical techniques used for estimation. The board characteristics chosen are board size (BS) and proportion of outside directors (PO). Both are important internal governance mechanisms that may impact the efficiency of the board. The variable, BS is the total number of members sitting on the board and PO is the percentage of outside directors out of the total number of directors. The data for BS and PO has been collected from ProwessIQ ${ }^{1}$ database for the top $500 \mathrm{BSE}$ listed companies. Our statistical analysis tries to see if the changes in board structure have been similar and uniform across the different sectors or showcase significant differences across different sectors and time periods. The sample has been divided into two periods, i.e. 20022010 and 2011-2019, and a comparison has been made between sample means and variance of BS and PO for the two periods above. The study highlights whether the changes in the macro-environment have altered the board structure of Indian firms in the last two decades.

The analysis has been carried out using one-way ANOVA and the paired t-test. The one-way ANOVA method is used to compare whether two samples mean are significantly different or not and the paired t-test is used to measure the differences between sample means and variances of BS and PO for the two periods. We construct hypothesis $1\left(\mathrm{H} 1_{0}\right)$ that there is no significant difference in the mean values of board size (BS) and proportion of outside directors (PO) across different sectors and firm age-groups. To test $\mathrm{H}_{0}$, we try to measure sector-wise and year-wise variation in the mean values of variables (BS and PO) by using the one-way ANOVA technique. Next, we formulate our hypothesis $2\left(\mathrm{H}_{0}\right)$ that there is no significant difference in the mean values of BS and PO 
across different time periods. The hypotheses have been formulated to understand the efficiency of regulatory changes. To test $\mathrm{H} 2$, we make a comparison between mean values and variances for two data sets (2002-2010 and 2011-2019) using the paired t-test analysis.

Tables 1, 2, and 3 give us descriptive statistics of the variables based on the sectors, time periods and, age groups respectively. Table 1 presents mean BS and mean PO in different sectors of the manufacturing sector. The board size for the chosen sample varies from 4 to 22 members during the sample period 2002 to 2019 . The mean BS lies between 6 to 13 members and the mean PO ranges from 0.27 to 0.44 . The mean PO for some sectors during 2002 to 2019 is less than the mandatory requirements, as the data includes all the points from 2002 to 2019 and the requirement of one-third or $50 \%$ of independent directors came into force from 2011 onwards. The mean BS is the highest in the natural gas trading and distribution sector followed by minerals \& crude oil and the diversified manufacturing sector. There is only one company in the footwear sector that has a mean BS of about 6 members throughout the sample period. There are more than 80 banking and financial services companies having a board size of 11 members, on average and out of which $36 \%$ are outside directors.

TABLE 1. Average BS and Average PO in different sectors

\begin{tabular}{lccc}
\hline Industry & Number of firms & Average BS & Average PO \\
\hline Agricultural products & 1 & 9.53 & 0.44 \\
Minerals and crude oil & 5 & 12.99 & 0.27 \\
Vegetable oils \& products & 4 & 9.13 & 0.40 \\
Processed foods & 16 & 10.06 & 0.42 \\
Textiles & 11 & 9.19 & 0.41 \\
Footwear & 1 & 6.82 & 0.44 \\
Wood and paper & 6 & 11.89 & 0.39 \\
Chemical & 24 & 11.06 & 0.41 \\
Drugs \& pharmaceuticals & 40 & 9.73 & 0.42 \\
Cosmetics & 9 & 10.06 & 0.29 \\
Plastic and rubber & 18 & 10.39 & 0.44 \\
Cement and construction & 57 & 10.20 & 0.38 \\
Metal products & 21 & 11.37 & 0.39 \\
Consumer goods & 28 & 11.58 & 0.38 \\
Consumer electronics & 19 & 10.03 & 0.34 \\
Automobile & 37 & 10.43 & 0.36 \\
Natural gas trading \& distribution & 18 & 13.26 & 0.32 \\
Computer and technology & 52 & 9.82 & 0.38 \\
Wholesale \& retail trading & 28 & 9.60 & 0.34 \\
Hotels \& restaurants & 8 & 9.32 & 0.30 \\
Banking \& financial services & 88 & 11.06 & 0.36 \\
Diversified manufacturing & 9 & 11.73 & 0.36 \\
\hline Not: BS & & & \\
\hline
\end{tabular}

Note: BS and PO stand for Board Size and Proportion of Outside Directors respectively.

The board characteristics over the sample period are presented in Table 2. We can see that the average board size from 2002 to 2019 ranges between 8 to about 12 members but the average PO has increased drastically from $7 \%$ to $50 \%$ during this period. The lowest BS and PO was in the year 2002 and both the highest figures have been found in the last year of the sample period i.e., 2019. The average percentage for outside directors grew phenomenally from $7 \%$ to $27 \%$ in just 2 years i.e., 2002 to 2004. In the last twelve years of the sample period (2008 to 2019), PO has been consistently higher than $40 \%$. From the analysis of the data, it has emerged that in the initial years of the sample period, some companies did not fulfil the regulatory requirements of independent directors. However, over a period of time, most of the entities have adhered to the requirements of the Listing Agreement of having the minimum number of outside directors. It is confirmed by median PO which shows 50\% from 2010 to 2019 which was increased gradually after the year 2005 (see Table 2). The underlying benefits that independent directors bring to the board include reducing financial statement fraud (Sharma 2004) and earnings management (Klein 2002) through rigorous monitoring and discipline (Guo \& Masulis 2015). 
TABLE 2. Board characteristics over the sample period (2002-2019)

\begin{tabular}{ccccc}
\hline Year & Average BS & Median $B S$ & Average PO & Median PO \\
\hline 2002 & 8.40 & 10.00 & 0.07 & 0.00 \\
2003 & 9.33 & 9.50 & 0.09 & 0.00 \\
2004 & 9.78 & 10.00 & 0.27 & 0.00 \\
2005 & 9.78 & 10.00 & 0.30 & 0.27 \\
2006 & 9.67 & 10.00 & 0.33 & 0.36 \\
2007 & 9.84 & 10.00 & 0.34 & 0.38 \\
2008 & 10.13 & 10.00 & 0.39 & 0.43 \\
2009 & 10.54 & 10.00 & 0.41 & 0.47 \\
2010 & 10.63 & 10.00 & 0.43 & 0.50 \\
2011 & 10.49 & 10.00 & 0.44 & 0.50 \\
2012 & 10.48 & 10.00 & 0.45 & 0.50 \\
2013 & 10.61 & 10.00 & 0.45 & 0.50 \\
2014 & 10.70 & 10.00 & 0.46 & 0.50 \\
2015 & 11.15 & 11.00 & 0.45 & 0.50 \\
2016 & 10.88 & 11.00 & 0.46 & 0.50 \\
2017 & 10.75 & 10.00 & 0.46 & 0.50 \\
2018 & 11.06 & 11.00 & 0.48 & 0.50 \\
2019 & 11.64 & 11.00 & 0.50 & 0.50
\end{tabular}

Note: BS and PO stand for Board Size and Proportion of Outside Directors respectively.

The board characteristics have also been presented across varied age groups of firms in Table 3. The sample is highly diverse in terms of its age group, such that one firm is just a year old and at the same time, the maximum age of our sample firm is 159 years. We can see that the average BS ranges from 9 to 13 members and the average $\mathrm{PO}$ is from 0.32 to 0.57 . The firms in the age group from 100 to 139 have the maximum number of board members. It is interesting to note that the older companies in the sample in terms of age group, 140 to 159 have outside director representation of about $57 \%$, and younger firms from 1 to 19 years of age have the lowest proportion of outside directors. It has emerged from this analysis that older firms (in terms of age) have more outside members on their board than younger firms. It is also noteworthy that when we have classified firms according to their age group, all the firms show outside directorship of more than one-third of their directors, thus complying with the mandatory provisions of at least one-third outside directors.

TABLE 3. Average BS and PO across different age groups of firms

\begin{tabular}{ccc}
\hline Age group & Average $B S$ & Average PO \\
\hline $1-19$ & 9.65 & 0.33 \\
$20-39$ & 10.47 & 0.41 \\
$40-59$ & 11.52 & 0.38 \\
$60-79$ & 11.27 & 0.43 \\
$80-99$ & 11.20 & 0.45 \\
$100-119$ & 12.96 & 0.32 \\
$120-139$ & 13.12 & 0.40 \\
$140-159$ & 10.88 & 0.57 \\
\hline
\end{tabular}

Note: BS and PO stand for Board Size and Proportion of Outside Directors respectively.

\section{RESULTS}

In this section, the comparison of mean values of board characteristics (BS and PO) across different sectors (Table 4) and years (Table 5) has been made using a statistical tool, i.e., one-way ANOVA (analysis of variance). Table
4 displays BS and PO mean values for different sectors and whether the sector-wise variations are statistically significant. Due to heterogeneity in firm characteristics across different sectors, the study also showcases how different sectors responded to the changing regulatory environment over the years. The $F$-value indicates that 
the sector-wise variations in mean values for Indian firms are statistically significant. Hence, the null hypothesis $1\left(\mathrm{H} 1_{0}\right)$ that there is no significant difference in BS and PO across different sectors of Indian companies has been rejected.

Hence, the results in Table 4 are in line with the findings from Table 1, i.e., board characteristics; BS and PO differ across different sectors. The natural gas trading and distribution sector; and then, minerals and crude oil sector companies have the highest average board size. On the other hand, the footwear sector has the lowest average board size. Further, the variance is the highest in the case of minerals and crude oil, wood and paper, and agricultural products sector. When we look at the values of PO; agricultural products, footwear, and the plastic \& rubber sector have the highest percentage of outside directors on board while minerals and crude oil, cosmetics, and hotels \& restaurants have the lowest fraction of outside members. We can observe that in all sectors, the mean BS is not less than 6 members and PO is not less than $27 \%$.

TABLE 4. Sector-wise variations of mean values of BS and PO using one-way ANOVA

\begin{tabular}{|c|c|c|c|c|}
\hline One Way ANOVA & & & & \\
\hline Industry Group & Mean & Variance & Mean & Variance \\
\hline Agricultural products & 9.00 & 6.12 & 0.44 & 0.03 \\
\hline Minerals and crude oil & 12.27 & 11.23 & 0.27 & 0.02 \\
\hline Vegetable oils \& products & 9.13 & 2.03 & 0.40 & 0.02 \\
\hline Processed foods & 10.06 & 0.46 & 0.42 & 0.02 \\
\hline Textiles & 9.19 & 0.39 & 0.41 & 0.02 \\
\hline Footwear & 6.44 & 4.38 & 0.44 & 0.03 \\
\hline Wood and paper & 11.89 & 6.37 & 0.39 & 0.03 \\
\hline Chemical & 11.06 & 0.39 & 0.41 & 0.01 \\
\hline Drugs \& pharmaceuticals & 9.73 & 0.38 & 0.42 & 0.01 \\
\hline Cosmetics & 10.06 & 0.73 & 0.29 & 0.02 \\
\hline Plastic and rubber & 10.39 & 0.33 & 0.44 & 0.02 \\
\hline Cement and construction & 10.20 & 0.39 & 0.38 & 0.02 \\
\hline Metal products & 11.37 & 0.47 & 0.39 & 0.02 \\
\hline Consumer goods & 11.58 & 0.17 & 0.38 & 0.01 \\
\hline Consumer electronics & 10.03 & 0.54 & 0.34 & 0.01 \\
\hline Automobile & 10.43 & 0.19 & 0.36 & 0.01 \\
\hline Natural gas trading \& distribution & 13.26 & 1.54 & 0.32 & 0.02 \\
\hline Computer and technology & 9.82 & 0.28 & 0.38 & 0.02 \\
\hline Wholesale and retail trading & 9.60 & 0.67 & 0.34 & 0.02 \\
\hline Hotels \& restaurants & 9.32 & 0.85 & 0.30 & 0.02 \\
\hline Banking and financial services & 11.06 & 0.07 & 0.36 & 0.02 \\
\hline Diversified manufacturing & 11.73 & 1.48 & 0.36 & 0.02 \\
\hline F-Value & \multicolumn{2}{|c|}{20.30} & \multicolumn{2}{|c|}{2.354} \\
\hline P-Value & \multicolumn{2}{|c|}{0.00} & \multicolumn{2}{|c|}{0.001} \\
\hline
\end{tabular}

Note: BS and PO stand for Board Size and Proportion of Outside Directors respectively.

Table 5 exhibits the year-wise variation in sample means and variances in board characteristics by using the one-way ANOVA method and reports whether yearwise variations in BS and PO are statistically significant or not. The F-value depicts that the variations in mean values of yearly BS and PO are statistically significant. Thus, it can be noted that the null hypothesis $\left(\mathrm{H} 1_{0}\right)$ that there is no significant difference in board characteristics across different sectors and years, has been rejected. We can observe the consistency in our results obtained from Table 2. There may be slight differences but both the tables 2 and 4 indicate similar outcomes. Thus, the significant differences in BS and PO across different sectors (Table 4) and across different time periods (Table 5) are apparent.

The SEBI Listing Obligation and Disclosure Requirements stated that the top 1000 listed companies should have at least six 6 board members by April 1, 2019 , and top 2000 companies, by April 1,2020². We can observe that for all the years, the mean BS is not less than 
6 members. However, it does not imply that all companies had more than 6 board members since 2002. For better representation of trends in board size, we have attached Tables A1 and A2 in Appendices which gives the number of companies along with the respective board size over the sample period. The mean PO after the year 2010 is more than $40 \%$, again it may not imply that all companies maintained this percentage. For more clarity, refer to Tables A3 and A4 in Appendices for the percentage of outside directors over the years.

TABLE 5. Year-wise variations in BS and PO using one-way ANOVA

\begin{tabular}{|c|c|c|c|c|}
\hline \multirow[t]{2}{*}{ Year } & \multicolumn{2}{|c|}{$B S$} & \multicolumn{2}{|c|}{$P O$} \\
\hline & Mean & Variance & Mean & Variance \\
\hline 2002 & 8.77 & 14.98 & 0.07 & 0.00 \\
\hline 2003 & 9.33 & 3.13 & 0.08 & 0.00 \\
\hline 2004 & 9.78 & 2.40 & 0.27 & 0.01 \\
\hline 2005 & 9.78 & 2.12 & 0.30 & 0.01 \\
\hline 2006 & 9.67 & 2.17 & 0.33 & 0.01 \\
\hline 2007 & 9.84 & 2.48 & 0.34 & 0.01 \\
\hline 2008 & 10.13 & 2.61 & 0.39 & 0.01 \\
\hline 2009 & 10.54 & 3.91 & 0.41 & 0.00 \\
\hline 2010 & 10.63 & 3.43 & 0.43 & 0.00 \\
\hline 2011 & 10.49 & 2.92 & 0.44 & 0.00 \\
\hline 2012 & 10.48 & 3.90 & 0.45 & 0.00 \\
\hline 2013 & 10.61 & 2.83 & 0.45 & 0.00 \\
\hline 2014 & 10.70 & 2.74 & 0.46 & 0.00 \\
\hline 2015 & 11.15 & 2.08 & 0.45 & 0.00 \\
\hline 2016 & 10.88 & 1.83 & 0.46 & 0.00 \\
\hline 2017 & 10.75 & 1.56 & 0.46 & 0.00 \\
\hline 2018 & 11.06 & 1.60 & 0.48 & 0.00 \\
\hline 2019 & 11.64 & 2.73 & 0.50 & 0.00 \\
\hline F-Value & \multicolumn{2}{|c|}{3.35} & \multicolumn{2}{|c|}{69.88} \\
\hline P-Value & \multicolumn{2}{|c|}{0.00} & \multicolumn{2}{|c|}{0.00} \\
\hline
\end{tabular}

Note: BS and PO stand for Board Size and Proportion of Outside Directors respectively.

To compare mean values and variances for two periods (2002-2010 and 2011-2019), the paired t-test has been used in Table 6 . The two periods were selectively considered to see the impact of government policy changes over this time period. The results indicate that the average BS and PO in the second sub-period is more than the first sub-period. Further, differences in mean values of board size are statistically significant at $1 \%$ significance level for the two different time periods. Thus, we may observe significant differences in BS and PO in the two periods. Consequently, the null hypothesis $\left(\mathrm{H} 2{ }_{0}\right)$ that there is no significant difference in BS and PO during two time period regimes has been rejected.

TABLE 6. Mean values and variances for two data sets (2002-2010 and 2011-2019) using paired t-test

\begin{tabular}{|c|c|c|c|c|}
\hline \multirow[t]{2}{*}{ Paired sample t-test } & \multicolumn{2}{|c|}{ BS } & \multicolumn{2}{|c|}{$\mathrm{PO}$} \\
\hline & $2002-2010$ & 2011-2019 & $2002-2010$ & 2011-2019 \\
\hline Mean & 9.83 & 10.86 & 0.29 & 0.46 \\
\hline Variance & 0.33 & 0.14 & 0.02 & 0.00 \\
\hline Observations & 9 & 9 & 9 & 9 \\
\hline
\end{tabular}




\begin{tabular}{|c|c|c|}
\hline Pearson correlation & 0.75 & 0.70 \\
\hline Mean difference & 0.00 & 0.00 \\
\hline Degrees of freedom (DF) & 8.00 & 8.00 \\
\hline t-statistic & -8.09 & -4.28 \\
\hline $\mathrm{P}(\mathrm{T}<=\mathrm{t})$ one-tail & 0.00 & 0.00 \\
\hline t Critical one-tail & 1.86 & 1.86 \\
\hline $\mathrm{P}(\mathrm{T}<=\mathrm{t})$ two-tail & 0.00 & 0.00 \\
\hline t Critical two-tail & 2.31 & 2.31 \\
\hline
\end{tabular}

Note: BS and PO stand for Board Size and Proportion of Outside Directors respectively.

\section{CONCLUSION}

In order to improve accountability and transparency in the corporate sector, many countries have developed corporate governance frameworks for better disclosures, regulations, codes, and principles. These guidelines concentrate on the board practices, its composition, remuneration, etc. for effective corporate governance, and continuous scrutiny by the Ministry of Corporate Affairs and SEBI leads to a perennial change in laws related to corporate governance. The law evolved with the substitution of the company's directors with government nominees, the inclusion of women independent directors, and recently, ruling out CEO duality. However, the corporate boards have been in the news bulletin once again after the fall of the corporate giants like Jet Airways, Yes Bank, Kingfisher Airlines and DHFL, etc. Although the insolvency law and Goods and Services Tax, etc. were blamed for this, failure to comply with corporate governance legislations could not be ruled out. More recently, the government dismissed the 15-member board of Infrastructure Leasing \& Financial Services (IL\&FS) to improve investor trust scalded by the firm's defaults and fears of a credit freeze. This series of scandals disseminated profound discontent among shareholders raising questions regarding the competency of boards, their namesake independence, and falling shareholder value (Vint et al. 1998; Sherman \& Chaganti 1998).

Our study makes a contribution to the existing corporate governance literature by comprehending trends and patterns in board characteristics such as size and independence. The sector-wise and year-wise variations in the mean values of board characteristics have been analyzed. The sample means and variance of BS and PO from two time periods (2002-2010 and 20112019) have also been measured. The analysis has been conducted using ANOVA and paired t-test methods. The findings suggest that there is a significant difference in the board size and proportion of outside directors across different sectors and sample periods and also during the time-period regimes. The results confirm significant change across the two important governance mechanisms highlighting the impact of governance reforms, which led to the deployment of larger boards and more independent members. The regulatory reforms can be treated as crucial milestones towards developing stronger corporate governance mechanisms in India and regulators may deliberate on taking the reforms to the next level.

Although the study has done an in-depth analysis of the two important board characteristics, still a few questions warrant the attention of future researchers. As we document significant changes in board size and proportion of independent directors over the two periods, it would be important to understand the reasons or the underlying factors other than compliance which has led to the increase. The rise in board size can be linked to the requirement of expertise at the top level with diverse knowledge, especially when the companies increase in size and have a diversity of operations. Further, the same can also be linked to stakeholder activism where institutional investors having a stake in the company appoint a board of directors so that they have a greater say in the company's decision-making. Different perspectives have been shared on the size of the board in a company. For example, larger boards are linked with more competencies, intellect, and strategic capabilities as the members carry different backgrounds, exposure, and skillset. But at the same time, the large boards may have conflicts of interest and delayed decision-making. Smaller boards have the advantage of better coordination and quick decisions with fewer conflicts, but they may be deprived of benefits coming out of diversity. Furthermore, as the study documented higher mean scores for specific sectors, the reasons for the same should also be studied. Additionally, the qualitative aspects of the board of directors including qualifications, experience, technical knowledge, etc. could also be analyzed for knowing the reasons for increased board size.

Similarly, the reasons for the change in the proportion of outside directors should be examined in view of the insertion of Section 212(14A) in The Companies Act which increased the liability of independent directors. Consequently, the appointment of independent directors in companies has not been an easy task ${ }^{3}$. Compliance with the regulatory framework (i.e., at least $50 \%$ independent directors) poses and presents many challenges. There is a need for a more robust, transparent, and professional approach in the appointment process of independent directors. The factors which restrict the appointment and 
functioning of independent directors should be examined in detail by future researchers.

Scholars in the related area may ponder over the company's strategic choices being followed for the functioning of their internal governance mechanism. Further, it may be evaluated how internal governance mechanisms are in alignment with the external governance systems for better performance and decision-making. The study is not free from shortcomings; it is confined to analyzing the patterns in the Indian board structure but has not examined the effects of board characteristics on firm performance like many other studies. The reason is there are already countless studies examining the association between these internal governance mechanisms and firm performance, but there are only a few which analyzed the board trends. Also, the chosen sample was for the top 500 listed firms; the findings may not be consistent for other listed or unlisted firms. The top 500 listed firms act more proactively and accountably to follow legislative guidelines.

\section{NOTES}

1 The Prowess database contains financial and corporate governance data on Indian listed and unlisted companies. It acquires its data from companies' audited Annual Reports and information submitted to the Ministry of Company Affairs.

2 https://www.primedatabase.com/article/2019/Article-M. Thenmozhi.pdf

3 https://www.primedatabase.com/article/2017/12.ArticleU.D.Choubey.pdf

\section{ACKNOWLEDGEMENT}

We are indebted to the anonymous reviewers and the journal editors for their valuable comments and suggestions.

\section{REFERENCES}

Amin, S.I.M. \& Nor, S.M. 2019. Board diversity and firm performance in the construction, manufacturing, and trading/services industries. Asian Journal of Accounting and Governance 12: 183-193.

Arora, A. 2020. Empirical evidence on optimal board size for Indian listed companies. International Journal of Corporate Governance 11(3): 341-353.

Arora, A. \& Sharma, C. 2015. Impact of firm performance on board characteristics: Empirical evidence from India. IIM Kozhikode Society \& Management Review 4(1): 53-70.

Arora, A. \& Sharma, C. 2016. Corporate governance and firm performance in developing countries: Evidence from India. Corporate Governance 16(2): 420-436.

Azmi, A.C., Hassan, N.A. \& Manawadu, I. 2020. The influence of director networks and independent directors on tax aggressiveness in financial reports. Asian Journal of Accounting and Governance 13: 67-75.
Baysinger, B.D. \& Butler, H.N. 1985. Corporate governance and the board of directors: Performance effects of changes in board composition. Journal of Law, Economics and Organization 1(1): 101-124.

Bhatt, R.R. \& Bhattacharya, S. 2015. Board structure and firm performance in Indian IT firms. Journal of Advances in Management Research 12(3): 232-248.

Blair, M. 1995. Ownership and Control: Rethinking Corporate Governance for The Twenty-First Century. Washington DC: Brookings Institution.

Cadbury Committee. 1992. Report of The Committee on The Financial Aspects of Corporate Governance. United Kingdom: Financial Reporting Council.

Coles, J.L., Daniel, N.D. \& Naveen, L. 2008. Boards: Does one size fit all?. Journal of Financial Economics 87(2): 329-356.

Dalton, D.R., Daily, C.M., Ellstrand, A.E. \& Johnson. J.L. 1999. Number of directors and financial performance: A metaanalysis. The Academy of Management Journal 42(6): 674-686.

Eisenberg, T., Sundren, S. \& Wells, M. 1998. Larger board size and decreasing firm value in small firms. Journal of Financial Economics 48(1): 35-54.

Fama, E.F. \& Jensen, M.C. 1983. Separation of ownership and control. Journal of Law and Economics 26(2): 301-325.

Goodstein, J., Gautam, K. \& Boeker, W. 1994. The effects of board size and diversity on strategic change. Strategic Management Journal 15(3): 241-250.

Guest, P.M. 2008. The determinants of board size and composition: Evidence from the UK. Journal of Corporate Finance 14(1): 51-72.

Guha, S.K., Samanta, N., Majumdar, A., Singh, M. \& Bharadwaj, A. 2019. Evolution of corporate governance in India and its impact on the growth of the financial market: An empirical analysis. Corporate Governance 19(5): 945-984.

Guo, L. \& Masulis, R.W. 2015. Board structure and monitoring: New evidence from CEO turnovers. The Review of Financial Studies 28(10): 2770-2811.

Gupta, P.K. \& Shallu, S. 2014. Evolving legal framework of corporate governance in India- Issues and challenges. Juridical Tribune/Tribuna Juridica 4(2): 240-253.

Hashim, F., Embong, Z. \& Phoey, W.B. 2021. The role of family ownership in the relationship between board characteristics and corporate social environmental reporting: Evidence from Malaysia. Asian Journal of Accounting and Governance 16: 1-17.

Herman, E.S. 1981. Corporate Control, Corporate Power. New York: Cambridge University Press.

John, K. \& Senbet, L.W. 1998. Corporate governance and board effectiveness. Journal of Banking and Finance 22(4): 371-403.

Klein, A. 2002. Audit committee, board of director characteristics and earnings management. Journal of Accounting and Economics 33(3): 375-400.

Kumar, N. \& Singh, J.P. 2013. Effect of board size and promoter ownership on firm value: Some empirical findings from India. Corporate Governance 13(1): 88-98.

Le, N.N.D. \& Thi, N.N.D. 2016. An examination of the relationship of corporate governance to firm performance: Empirical evidence from Vietnamese listed companies. International Journal of Financial Research 7(4): 190-197. 
Patro, S., Lehn, K. \& Zhao, M. 2009. Determinants of the size and structure of corporate boards: 1935-2000. Financial Management 38: 1-57.

Ley, L.A., Hashim, F. \& Embong, Z. 2019. Board characteristics, investors' confidence and firm value: Malaysian evidence. Asian Journal of Accounting and Governance 12: 169-181.

Linck, J.S., Netter, J.M. \& Yang, T. 2008. The effects and unintended consequences of the Sarbanes-Oxley Act on the supply and demand for directors. Review of Financial Studies 22(8): 3287-3328.

Martin, C.J.G. \& Herrero, B. 2018. Boards of directors: Composition and effects on the performance of the firm. Economic Research-Ekonomska Istraživanja 31(1): 1015-1041.

Matter, E. \& Ball, M. 1985. Handbook for Corporate Directors. New York: McGraw Hill \& Ball.

Mehrotra, S. 2015. Corporate board structure in the United States and India: A Comparative View. Indian Journal of Corporate Governance 8(2): 166-186.

Mishra, S. 2020. Do independent directors improve firm performance? Evidence from India. Global Business Review.

Monks, R.A.G. \& Minow, N. 2001. Corporate Governance. Securities and Exchange Commission 1980. Malden, MA: Blackwell.

Nguyen, T.T.M., Evans, E. \& Lu, M. 2017. Independent directors, ownership concentration and firm performance in listed companies: Evidence from Vietnam. Pacific Accounting Review 29(2): 204-226.

Onyina, P.A. \& Gyanor, D.K. 2019. Do corporate governance practices affect the performance of firms listed on the Ghana Stock Exchange? Corporate Ownership \& Control 17(1): 107-115.

Ponomareva, Y., Federo, R., Aguilera, R. \& Collin, S.O. 2021. The cost of conformity to good governance: Board design and compensation. Corporate Governance: An International Review.

Rosenstein, S. \& Wyatt, J.G. 1990. Outside directors, board independence and shareholder wealth. Journal of Financial Economics 26(2): 175-191.
Roy, A. 2016. Corporate governance and firm performance: A study of Indian listed firms. Metamorphosis: A Journal of Management Research 15(1): 31-46.

Sharma, V.D. 2004. Board of director characteristics, institutional ownership and fraud: Evidence from Australia. Auditing: $A$ Journal of Practice \& Theory 23(2): 107-119.

Sherman, H. \& Chaganti, R. 1998. Corporate Governance and The Timeliness of Change: Reorientation in 100 American Firms. Praeger Pub Text.

Shikha, N. 2017. Corporate governance in India- the paradigm shift. International Journal of Corporate Governance 8(2): 81-105.

Soni, T.K. \& Singh, A. 2020. Directors' remuneration, corporate governance and firm performance linkages: Evidence from the emerging country. Corporate Ownership \& Control 18(1): 382-392.

Vaidya, P.N. 2019. Board size and firm performance: A study on BSE 100 companies. Journal of Management 6(3): 117-123.

Vint, A., Gould, D. \& Recaldin, C. 1998. Learning to Fly: Leadership and Performance in The Boardroom. London: Kogan Page.

Williamson, O.E. 1996. The Mechanisms of Governance. New York: Oxford University Press.

Tarun K Soni

Lal Bahadur Shastri Institute of Management

Sector 11, Dwarka

New Delhi- 110075

INDIA.

E-mail: tarun@lbsim.ac.in

Akshita Arora*

Apeejay School of Management

Sector VIII, Dwarka

New Delhi- 110077

INDIA.

E-mail: akshitaarora1989@gmail.com

${ }^{*}$ Corresponding author

\section{APPENDICES}

TABLE A1. Board size along with the number of companies during the years 2002 to 2010

\begin{tabular}{cccccccccc}
\hline Board Size & 2002 & 2003 & 2004 & 2005 & 2006 & 2007 & 2008 & 2009 & 2010 \\
\hline 4 & 5 & 16 & 8 & 9 & 12 & 8 & 7 & 7 & 6 \\
5 & 11 & 16 & 14 & 19 & 23 & 17 & 11 & 8 & 6 \\
6 & 15 & 16 & 20 & 23 & 24 & 22 & 22 & 25 & 25 \\
7 & 17 & 22 & 18 & 25 & 31 & 28 & 26 & 30 & 32 \\
8 & 17 & 32 & 34 & 38 & 27 & 47 & 49 & 41 & 43 \\
9 & 26 & 34 & 43 & 32 & 47 & 42 & 42 & 38 & 41 \\
10 & 27 & 26 & 29 & 40 & 48 & 43 & 59 & 60 & 61 \\
11 & 19 & 29 & 38 & 29 & 34 & 35 & 35 & 33 & 31 \\
12 & 16 & 26 & 35 & 37 & 37 & 32 & 46 & 35 & 41 \\
13 & 13 & 15 & 20 & 22 & 20 & 23 & 26 & 30 & 32 \\
14 & 8 & 14 & 13 & 16 & 14 & 26 & 18 & 20 & 14 \\
\hline
\end{tabular}




\begin{tabular}{|c|c|c|c|c|c|c|c|c|c|}
\hline 15 & 9 & 10 & 15 & 12 & 14 & 15 & 14 & 17 & 18 \\
\hline 16 & 7 & 4 & 9 & 8 & 12 & 11 & 10 & 10 & 12 \\
\hline 17 & 4 & 4 & 10 & 8 & 8 & 8 & 5 & 10 & 6 \\
\hline 18 & 2 & 3 & 4 & 7 & 2 & 3 & 7 & 6 & 9 \\
\hline 19 & 4 & 2 & 0 & 3 & 2 & 4 & 4 & 6 & 5 \\
\hline 20 & 1 & 3 & 1 & 1 & 4 & 0 & 1 & 4 & 5 \\
\hline 22 & 0 & 0 & 0 & 0 & 0 & 0 & 0 & 0 & 0 \\
\hline
\end{tabular}

TABLE A2. Board size along with the number of companies during the years 2011 to 2019

\begin{tabular}{cccccccccc}
\hline Board Size & 2011 & 2012 & 2013 & 2014 & 2015 & 2016 & 2017 & 2018 & 2019 \\
\hline 4 & 5 & 3 & 10 & 7 & 2 & 0 & 0 & 0 & 0 \\
5 & 7 & 11 & 6 & 10 & 6 & 6 & 7 & 5 & 2 \\
6 & 31 & 24 & 28 & 26 & 6 & 15 & 17 & 15 & 6 \\
7 & 21 & 37 & 35 & 28 & 32 & 25 & 19 & 18 & 29 \\
8 & 51 & 46 & 40 & 34 & 43 & 47 & 49 & 40 & 27 \\
9 & 41 & 51 & 42 & 55 & 44 & 56 & 57 & 56 & 39 \\
10 & 67 & 53 & 62 & 56 & 40 & 56 & 66 & 71 & 57 \\
11 & 25 & 37 & 39 & 43 & 63 & 55 & 46 & 53 & 71 \\
12 & 44 & 40 & 37 & 40 & 38 & 44 & 52 & 50 & 43 \\
13 & 27 & 29 & 28 & 27 & 40 & 39 & 34 & 36 & 47 \\
14 & 25 & 26 & 21 & 25 & 36 & 27 & 30 & 27 & 30 \\
15 & 16 & 13 & 22 & 16 & 18 & 17 & 21 & 18 & 20 \\
16 & 14 & 10 & 10 & 17 & 13 & 14 & 11 & 8 & 13 \\
17 & 9 & 6 & 9 & 6 & 13 & 11 & 4 & 9 & 14 \\
18 & 5 & 6 & 3 & 5 & 3 & 2 & 2 & 5 & 8 \\
19 & 3 & 8 & 4 & 3 & 1 & 2 & 2 & 5 & 4 \\
20 & 2 & 3 & 4 & 4 & 3 & 1 & 2 & 1 & 3 \\
22 & 0 & 0 & 0 & 1 & 1 & 0 & 0 & 0 & 1 \\
\hline
\end{tabular}

TABLE A3. Proportion of outside directors along with the number of companies during the years 2002 to 2010

\begin{tabular}{|c|c|c|c|c|c|c|c|c|c|}
\hline $\begin{array}{l}\text { Proportion } \\
\text { of outside } \\
\text { directors }\end{array}$ & 2002 & 2003 & 2004 & 2005 & 2006 & 2007 & 2008 & 2009 & 2010 \\
\hline $0-0.1$ & 343 & 336 & 218 & 188 & 152 & 128 & 94 & 85 & 69 \\
\hline $0.1-0.2$ & 2 & 1 & 5 & 9 & 3 & 4 & 7 & 10 & 5 \\
\hline $0.2-0.3$ & 11 & 8 & 14 & 24 & 22 & 30 & 24 & 17 & 13 \\
\hline $0.3-0.4$ & 13 & 9 & 30 & 34 & 52 & 52 & 65 & 46 & 44 \\
\hline $0.4-0.5$ & 17 & 17 & 31 & 27 & 41 & 52 & 56 & 64 & 62 \\
\hline $0.5-0.6$ & 20 & 26 & 55 & 70 & 77 & 94 & 97 & 128 & 149 \\
\hline $0.6-0.7$ & 12 & 19 & 43 & 43 & 55 & 39 & 53 & 51 & 54 \\
\hline $0.7-0.8$ & 3 & 7 & 21 & 21 & 15 & 18 & 17 & 17 & 23 \\
\hline $0.8-0.9$ & 2 & 0 & 6 & 7 & 6 & 6 & 7 & 2 & 2 \\
\hline $0.9-1$ & 1 & 1 & 1 & 1 & 1 & 1 & 4 & 4 & 3 \\
\hline
\end{tabular}


TABLE A4. Proportion of outside directors along with the number of companies during the years 2011 to 2019

\begin{tabular}{ccccccccccc}
\hline $\begin{array}{c}\text { Proportion } \\
\text { of outside } \\
\text { directors }\end{array}$ & 2011 & 2012 & 2013 & 2014 & 2015 & 2016 & 2017 & 2018 & 2019 \\
\hline $0-0.1$ & 60 & 55 & 48 & 43 & 29 & 21 & 11 & 6 & 6 \\
$0.1-0.2$ & 3 & 8 & 6 & 6 & 9 & 7 & 4 & 3 & 2 \\
$0.2-0.3$ & 18 & 14 & 13 & 24 & 29 & 14 & 26 & 15 & 9 \\
$0.3-0.4$ & 39 & 32 & 40 & 33 & 50 & 58 & 51 & 54 & 32 \\
$0.4-0.5$ & 66 & 65 & 61 & 72 & 81 & 77 & 69 & 87 & 107 \\
$0.5-0.6$ & 146 & 150 & 168 & 158 & 159 & 174 & 192 & 181 & 168 \\
$0.6-0.7$ & 61 & 71 & 50 & 57 & 49 & 58 & 51 & 62 & 80 \\
$0.7-0.8$ & 24 & 23 & 30 & 22 & 10 & 11 & 14 & 13 & 18 \\
$0.8-0.9$ & 7 & 6 & 7 & 8 & 5 & 4 & 6 & 2 & 2 \\
$0.9-1$ & 0 & 0 & 1 & 1 & 3 & 0 & 0 & 1 & 0 \\
\hline
\end{tabular}

